\title{
THE PRINCIPLE OF SELF SUBMISSION IN DIVORCES CASES FROM THE PERSPECTIVE OF LEGAL CERTAINTY
}

\author{
Haqqiyah Uthlufah \\ Student of Magister Program, Universitas Islam Negeri Maulana Malik Ibrahim, \\ Malang, Indonesia \\ email: haqqiyah@gmail.com
}

\begin{abstract}
The problem of the principle of submission in the divorce law in the Religious Court by a non-Muslim couple occurs because the couple's marriage is based on Islamic law. What cannot be separated from Islamic law is Islamic family law because it is related to the faith of a Muslim. Islamic family law can only apply to Muslims and cannot apply to non-Muslims. The problem of the principle of submission to the divorce law was incomplete (incomplete norm) or the existence of a legal vacuum (vacuum of norm) in marriage law in Indonesia. This research is a legal research and is normative in nature. The approach used is statutory, case, and conceptual. The legal materials used are primary, secondary and tertiary. The method of collecting legal materials is first to qualify the facts and then to qualify the law. The analytical tool used is legal interpretation in the form of principal, systematic and grammatical interpretation.
\end{abstract}

\section{Keywords: Submission, Divorce Law, Legal Certainty.}

\section{Introduction}

The principle of submission in general is usually found in Islamic banking disputes because the transactors do not only include Islamic banking with Muslim customers. However, there is also a problem where the transactors are Islamic banking with non-Muslim customers. It can be concluded that the implementation of Islamic economic law is more flexible, namely not only for Muslims but also for nonMuslims. In contrast to Islamic family law (al-ahwal al-shakhshiyyah) which is specific and limited to Muslims. (Yasin, 2016).

The problem of the principle of submission in the divorce law by nonMuslim couples is found in 4 (four) decisions of the Religious Courts with the following details:

a. Decision Number 121 / Pdt.G / 2010 / PA.Pkc is a lawsuit for divorce. The case for the position of this ruling is that a couple who got married based on Islamic law later converted to Catholicism. This decision states that the Religious Courts have absolute authority to examine and try this case. Then, in the dictum of this verdict, the Defendant dropped one ba'in shughra divorce against the Plaintiff. 
b. Decision Number 0115 / Pdt.G / 2013 / PA.Ktp is a divorce case. The case for the position of this ruling is that a couple who married under Islamic law later embraced Protestant Christianity. This decision states that the Religious Courts have absolute authority to examine and try this case. Then, in the dictum of this decision, the Petitioner dropped one ba'in shughra divorce against the Respondent.

c. Decision Number 1226 / Pdt.G / 2013 / PA.SAL is a divorce case. The case for the position of this ruling is that a couple got married based on Islamic law and then converted to Catholicism. This decision states that the Religious Courts have absolute authority to examine and try this case. Then, in the dictum the decision makes the marriage of the parties nullify.

d. Decision Number 0044 / Pdt.G / 2014 / PA.Kab.Kdr is a lawsuit for divorce. The case for the position of this ruling is that a couple who married under Islamic law later embraced Protestant Christianity. This decision states that the Religious Courts have absolute authority to examine and try this case. Then, in the dictum the verdict states the marriage fasakh of the parties.

The spouses or parties in the 4 (four) decisions of the Religious Court are non-Muslim couples whose marriages are based on Islamic law and are registered at the Office of Religious Affairs who then file for divorce at the Religious Court because of the registration of the previous marriage.

Article 49 of Law Number 3 of 2006 concerning Amendments to Law Number 7 of 1989 concerning the Religious Courts determines that the Religious Courts have absolute competence, one of which is the field of marriage. The Religious Court has the duty and authority to examine, decide and settle cases at the first level between people who are Muslim in the field of: a) Marriage; b) inheritance; c) will; d) grants; e) waqf; f) zakat; g) infaq; h) shadaqah; and i) sharia economics. Problems that occur in a marriage that are registered at the Office of Religious Affairs are the authority of the Religious Court to examine, decide and resolve these problems (Sabaeni, 2008). However, it is generally known that the Environment of the Religious Courts is based on an Islamic personality. This is stipulated in Article 2 and Article 49 of Law Number 3 of 2006 concerning Amendments to Law Number 7 of 1989 concerning the Religious Courts.

A non-Muslim can become a party to litigate in the field of marriage provided that the party submitting the lawsuit or petition is a Muslim party (Harahap, 
2009) As for the two non-Muslim parties, there was no further explanation. From this explanation, it can be concluded that non-Muslim couples cannot litigate in the Religious Courts because those who filed the suit or petition were non-Muslims.

These problems occur because of the incomplete norm and the existence of a vacuum of norm in marriage law in Indonesia. As in Law Number 1 of 1974 concerning Marriage, Government Regulation Number 9 of 1975 and the Compilation of Islamic Law and the Law on Religious Courts which do not specify the mechanism for registering remarriage when the spouse leaves the religion for registering their marriage (Purbasari, 2017). As a result of the incomplete norm and the vacuum of norm, non-Muslim couples must use the religious law which legalizes their marriage if they come into contact with the law even though both have changed religions.

Incomplete norm and vacuum of norm at least cause 2 (two) problems, namely:

1. Pros and cons regarding what is the marital status, what court has the authority to resolve the problem and what the legal consequences are after the divorce.

2. Does not provide legal certainty to the parties. Whereas the law should be able to guarantee legal certainty for the community. (Mulyata, 2015)

This research uses legal certainty because it emphasizes that the results of the law or more specifically legislation are nothing but to guarantee and create legal certainty for the community. Legal certainty includes 4 (four) elements, namely certainty of rules or regulations, government and bureaucratic certainty, certainty or justice and social upheaval. There are 4 (four) decisions that have been mentioned are closely related to legal certainty.

\section{Legal Arguments Against the Principle of Submission by Non-Muslim Spouses in Divorce Law in Religious Courts}

Non-Muslim couples who submit themselves to divorce laws in the Religious Courts occur because their marriages are based on Islamic law and are registered at the Religious Affairs Office so that when a divorce occurs, they must be submitted to the Religious Court. This is found in 4 (four) decisions which are also the primary legal material in this study. The classification of the 4 (four) decisions is as follows: a. Decision Number 121 / Pdt.G / 2010 / PA.Pkc is a lawsuit for divorce. The case for the position of this decision is that a couple who got married based on Islamic law later 
converted to Catholicism; b. Decision Number 0115 / Pdt.G / 2013 / PA.Ktp is a divorce case. The case for the position of this ruling is that a couple who married under Islamic law later embraced Protestant Christianity; c. Decision Number 1226 / Pdt.G / 2013 / PA.SAL is a divorce case.

The case for the position of this decision is that a couple who got married based on Islamic law later converted to Catholicism; d. Decision Number 0044 / Pdt.G / 2014 / PA.Kab.Kdr is a lawsuit for divorce. The case for the position of this ruling is that a couple who married under Islamic law later embraced Protestant Christianity.

a. The classification of the 4 (four) decisions indicates that the parties are a nonMuslim spouse and the divorce case is submitted to the Religious Court which is then examined, tried and decided by the Religious Court. Meanwhile, the considerations of the Panel of Judges in accepting divorce cases in the 4 (four) decisions are as follows:

b. a. The consideration in Decision Number 121 / Pdt.G / 2010 / PA.Pkc is "considering, that although the Plaintiff and the Defendant are Catholic, as both parties acknowledge, which is also consistent with Exhibit P.2, but because of the legal relationship between the Plaintiff and When the defendant got married is based on Islamic law, PA Pangkalan Kerinci has the authority to examine and try this case."

c. b. The consideration in the Decision Number 0115 / Pdt.G / 2013 / PA.Ktp is "considering, that although the Petitioner and the Respondent are Protestant Christians, the marriage of the Petitioner and Respondent was carried out based on Islamic law so based on Article 49 letter (a) of Law Number 7 In 1989, which was amended by Law Number 3 of 2006 and the second amendment to Law Number 50 of 2009 concerning the Religious Courts, the PA has the authority to examine and try this case.

Meanwhile, another consideration is "considering, that because the Petitioner is a Protestant Christian, based on the Guidelines for the Implementation of Duties and Administration of the Religious Courts Book II of the Supreme Court, the Court handed down the divorce of one ba'in shughra of the Petitioner against the Respondent." The considerations in Decision Number 1226 / Pdt.G / 2013 / PA.SAL are "considering, that based on the Petitioner's petition which is corroborated by documentary evidence and testimony of witnesses in court, it is proven that this case 
is a divorce case filed by the Petitioner when he married the Respondent. both are Muslims and their marriage took place at the KUA which is within the scope of the City of Salatiga and is now located in the Salatiga PA jurisdiction, so according to Article 49 of Law Number 3 of 2006 concerning Amendments to Law Number 7 of 1989 and amended by Law Law Number 50 of 2009, this case is under the authority of PA Salatiga to examine and try it. "

The consideration in Decision Number 044 / Pdt.G / 2014 / PA.Kab.Kdr is "considering, that the Plaintiff is a non-Muslim religion, based on the principle of Islamic personality law which is one of several principles of civil procedural law for religious courts, the principle of Islamic personality is an inseparable relationship on the basis of legal considerations, that when the Plaintiff married the Defendant, both of them were Muslim, therefore the Panel of Judges was of the opinion that in this divorce case even though the non-Muslim Plaintiff in this case became the PA's absolute competence, the determining reason was the relationship marriage which was in effect at the time the marriage was carried out, thus the Plaintiff's claim can be accepted for further consideration. "

Meanwhile, another consideration is "considering, that the Plaintiff and Defendant are Christian, but at the time of their marriage, the Plaintiff and the Defendant are Muslim, so based on this, the Plaintiff has legal standing to file this case, it can be accepted and justified that the Plaintiff is a legal subject entitled filed an application for divorce for divorce in PA Kediri Regency. "

The consideration of the Panel of Judges in examining, adjudicating and deciding divorce cases for non-Muslim couples in the 4 (four) decisions is based on the legal relationship of the parties at the time of the marriage, namely based on Islamic law and registered at the Office of Religious Affairs. This is contrary to the principle of Islamic personality stipulated in Law Number 3 of 2006.

Legal considerations of the Panel of Judges that contradict the principle of Islamic personality occur because of the incomplete norm and the vacuum of norm and marriage law in Indonesia. As in Law Number 1 of 1974 concerning Marriage, Government Regulation Number 9 of 1975 and the Compilation of Islamic Law and the Law on Religious Courts which do not specify how to record remarriage when a married couple leaves the religion of registering their marriage. Due to the incomplete law (incomplete norm) and the existence of a legal vacuum (vacuum of norm), non- 
Muslim couples must use the religious law which legalizes their marriage if they come into contact with the law even though their status has changed religions.

The incomplete norm and the existence of a legal vacuum (vacuum of norm) above cannot be used as an excuse by the Panel of Judges for refusing to examine, try and decide the divorce case. This happens because the judicial power system in Indonesia adheres to the ius curia novit principle. Then, there were no legal considerations from the Panel of Judges in 4 (four) decisions that considered the ius curia novit principle. In fact, this principle is the most basic reason to be used as a legal basis for examining, trying and deciding the divorce case.

Ius curia novit or curia novit jus are judges who are considered to know all the laws so that the court must not refuse to examine, hear and decide cases (Harahap, 2006). The incomplete law (incomplete norm) and the existence of a legal vacuum (vacuum of norm) in Indonesian marriage law have also resulted in the ius curia novit principle in Law Number 48 of 2009 concerning Judicial Power and the principle of Islamic personality in Law Number 3 of 2006 when applied to the 4 (four) decisions, these decisions become mutually contradictory.

The contradiction of the 2 (two) principles when applied to the 4 (four) decisions is as follows:

a. On the one hand, the court cannot reject cases on the grounds that the law is incomplete (incomplete norm) and the existence of a legal vacuum (vacuum of norm) in marriages in Indonesia.

b. Meanwhile, on the other hand, when the case is accepted, it will be contrary to the principle of Islamic personality because the parties to the 4 (four) decisions are non-Muslim couples.

\section{The Principle of Submission by Non-Muslim Spouses to Divorce Law in Religious \\ Courts from the Perspective of Legal Certainty}

Even though, spiritual is inherent and personal affair but everybody has spiritual right. It needs legal protections (Setyowati, 2018), including in the legal certainty the competence of court in divorce cases while the spouses have converted out of Islam. Legal certainty can be seen from the consistency in the judges' decisions between the decisions of other judges for similar cases that have been decided. The court needs to follow the previous judge's decision in adjudicating cases similar to 
those that had been decided by the previous court. If for similar cases there is a big difference between court decisions in certain cities and court decisions in other cities, both in consideration and dictum, in a period that is not too different but one has permanent legal force. This will create legal uncertainty because the public does not know which ones to refer to when they are dealing with the court. This happened in 4 (four) decisions which became the primary legal material in this study.

As for simplifying the analysis in this sub-chapter, we will first provide conclusions from the legal considerations of the Panel of Judges in each decision which is the primary legal material in this study which will then be analyzed using 4 (four) elements of legal certainty. Thus, it will appear that there is legal uncertainty over the issue of the principle of submission by non-Muslim couples to divorce law in the Religious Courts.

\section{Legal Certainty}

The legal considerations mentioned by the Panel of Judges in 4 (four) decisions in matters or that intersect with the concerns of rules or regulations in 4 (four) decisions as follows:

1) Decision Number 121 / Pdt.G / 2010 / PA.Pkc

The Panel of Judges did not mention what rules were the legal basis for their deliberations. The Panel of Judges only states that they have the authority to examine, hear and decide this case even though the parties are Catholic who have been in accordance and proven by the confession and evidence presented. The Panel of Judges only mentions and considers because of the legal relationship between the parties when getting married based on Islamic law without mentioning or using a legal basis. Then, in the case of the Panel of Judges in their decision dictum that the Defendant gave the divorce to one ba'in sughra against the Plaintiff, it refers to Article 119 paragraph (2) Compilation of Islamic Law. The purpose of the Panel of Judges in their deliberations is that the divorce case has been handed down by the Court. however, in terms of dropping the divorce of one ba'in sughra on a non-Muslim spouse is not appropriate.

In fact, the meaning of talak ba in shughra in Article 119 paragraph (1) is divorce which cannot be referred to but may be a new marriage contract with her exhusband even though it is in idah (Syaifuddin, 2014). Meanwhile, people who are 
Catholic cannot be subject to Islamic law because the enforcement of religious law is itself a belief.

Legal considerations and the dictum of the decision are not appropriate if it is decided against a non-Muslim partner so it is very appropriate if the application of the law does not only originate from legal justice, in the sense that it is only based on the sound of the relevant legal principles. Law is also inseparable from morality and justice so that every law application should contain moral and justice demands.

1) Decision Number 0115 / Pdt.G / 2013 / PA.Ktp

The consideration of the Panel of Judges in declaring that they have the authority to examine, try and decide this case even though the parties are Protestant Christians is because the marriage of the parties was carried out based on Islamic law and refers to Article 49 letter a of Law Number 7 of 1989 which has been amended by Law -Law Number 3 of 2006 and the second amendment to Law Number 50 of 2009 concerning the Religious Courts.

In fact, Article 49 of Law Number 3 of 2006 stipulates that the Religious Courts have the duty and authority to examine, decide and settle cases at the first level between Muslims, one of which is in the field of marriage. The Panel of Judges is also of the opinion that because the Petitioner is a Protestant Christian, the Petitioners will be subject to divorce one ba'in shughra against the Respondent based on the Guidelines for the Implementation of Tasks and Administration of the Religious Courts Book II of the Supreme Court. In this case, the Guidelines for the Implementation of the Duties and Administration of the Religious Courts Book II of the Supreme Court, which edition, were not explained, caused confusion in terms of referring to the basis.

It should also be noted that this book is only a guideline that aims to minimize disparities in decisions. Thus, it is more appropriate for the Panel of Judges to refer to statutory regulations such as the Islamic Law Compilation which also determines talak ba'in sughra. Then, in the case of the Panel of Judges, in their dictum, the decision which resulted in the divorce of one ba'in sughra from the Defendant against the Plaintiff was incorrect.

The meaning of talak ba in shughra in Article 119 paragraph (1) is divorce which cannot be referred to but may be a new marriage contract with her ex-husband 
even though it is in idah. Meanwhile, people who are Protestant Christians cannot be subject to Islamic law because the enforcement of religious law is itself a belief.

Legal considerations and the dictum of the decision are not appropriate if it is decided against a non-Muslim partner so it is very appropriate if the application of the law does not only originate from legal justice, in the sense that it is only based on the sound of the relevant legal principles. Law is also inseparable from morality and justice so that every law application should contain moral and justice demands.

Decision Number 1226 / Pdt.G / 2013 / PA.SAL

The Panel of Judges is of the opinion that the Petitioner has the legal standing to apply for this divorce application in accordance with Article 14 of Government Regulation Number 9 of 1975 in conjunction with Article 66 of Law Number 7 of 1989 which has been amended by Law Number 3 of 2006 and Law Number 50 of 2009.

Article 14 of Government Regulation No. 9 of 1975 does determine the procedure for divorce for husbands who have married according to Islam. However, this would contradict the principle of Islamic personality in Law Number 3 of 2006. In addition, because the hierarchy of Government Regulation Number 9 of 1975 was under the hierarchy of laws and based on the year Government Regulation Number 9 of 1975 was issued, it was too far away. when compared to Law Number 3 of 2006. In other words, Government Regulation Number 9 of 1975 is very behind.

The Panel of Judges is of the opinion that this case is the authority of the Salatiga Religious Court to examine and try it because the parties when married were Muslim and the marriage took place at the Office of Religious Affairs which is within the scope of the City of Salatiga and is now located in the jurisdiction of the Salatiga Religious Court, which is in accordance with Article 49 of the Law -Law Number 3 of 2006 concerning Amendments to Law Number 7 of 1989 and amended by Law Number 50 of 2009.

In fact, Article 49 of Law Number 3 of 2006 stipulates that the Religious Courts have the duty and authority to examine, decide and settle cases at the first level between Muslims, one of which is in the field of marriage. When the parties are married to Islam and their marriage is carried out according to Islamic law as proven, but now the parties have converted to Catholicism as the Petitioner admits in his 
petition, therefore the Petitioner's divorce must be imposed by the Religious Court by abusing the Petitioner's marriage and Respondent.

The dictum above which decides on the marriage of a non-Muslim spouse is appropriate when compared to the Panel of Judges who decided with the divorce of one ba'in sughra. The dictum of the decision is more appropriate because the term fasakh in fiqh munakahat is a form of divorce or a statement of divorce because a judge's decision (court) is a form of divorce that husband and wife do not really want, but divorce must occur solely because of a Islamic order (religion). In the divorce law, divorce does not require the activities of the husband who was originally the holder of the right to divorce, but the husband's divorce is transferred to waliy al-amri in a positive legal perspective in Indonesia, the divorce becomes the judge's authority to overthrow him or commonly referred to as ex officio rights.

The Panel of Judges in Decision Number 0044 / Pdt.G / 2014 / PA.Kab.Kdr is of the opinion that even though the Plaintiff is non-Muslim, based on the principle of Islamic personality which is one of the principles of procedural law for the Religious Courts, this divorce case is and becomes the competence of the PA because what determines is the marital relationship in effect at the time the marriage is carried out. The Panel of Judges also believes that the Plaintiff also has legal standing to file this case.

The Assembly's considerations above are not appropriate because they are based on the principle of Islamic personality. As previously explained, the principle of Islamic personality in Article 2 of Law Number 3 of 2006 which determines that the Religious Court is one (1) actor of judicial power for people seeking justice who are Muslims regarding certain cases. (Suleman, 2010)

This article does not mention how the marriage takes place because it focuses more on the word "being Muslim" which indicates religion at the time of the dispute. This is also strengthened by the process of checking the identity of the parties as evidenced by an Identity Card issued by the authorized agency.

The Panel of Judges is also of the opinion that the Petitioner has the legal standing to submit an application to the Religious Court because the marriage of the parties is conducted in the presence of a Marriage Registration Officer at the Office of Religious Affairs. The consideration of the Panel of Judges, which states that the parties' marriages are carried out based on Islamic law so that they have the legal 
standing to submit an application to the Religious Court while the parties are nonMuslims result in submission to the divorce law in the Religious Court by non-Muslim couples.

Then, the consideration of the Panel of Judges in stating the principles of marriage between non-Muslim couples was correct when compared to the Panel of Judges who decided with the divorce of one ba'in sughra. The dictum of the decision is more appropriate because the term fasakh in fiqh munakahat is a form of divorce or a statement of divorce because a judge's decision (court) is a form of divorce that husband and wife do not really want, but divorce must occur solely because of a syar order. 'i (religion). In the divorce principle, the husband's activity does not require the activity of the husband who was originally the holder of the right to divorce, but the husband's divorce has been transferred to waliy al-amri in a positive legal perspective in Indonesia, the divorce becomes the judge's authority to overthrow him or commonly referred to as ex officio rights.

The legal considerations mentioned by the Panel of Judges in the 4 (four) decisions of the Religious Courts above occurred due to the incomplete law (incomplete norm) and the existence of a legal vacuum (vacuum of norm) in marriage law in Indonesia. Both Law Number 1 of 1974 concerning Marriage, Government Regulation Number 9 of 1975 and the Compilation of Islamic Law and the Law on Religious Courts. Due to the incomplete law (incomplete norm) and the existence of a legal vacuum (vacuum of norm), non-Muslim couples, in this case, the parties must use religious law which legalizes their marriage if it collides with the law even though their status has changed religions. Because of these considerations, a non-Muslim couple has submitted to the divorce law.

In fact, there should not be submission to divorce law in the Religious Courts because the law in Indonesia, in particular can be found in Law Number 3 of 2006 which only recognizes the principle of submitting oneself to Islamic banking disputes because the perpetrators of transactions are not only Islamic banking with Muslim customers. However, there are also disputes in which the transactors are Islamic banking with non-Muslim customers. The non-Muslim couple's submission to divorce law in the Religious Courts also occurs because of the marriage law in Indonesia. Both Law Number 1 of 1974 concerning Marriage, Government Regulation Number 9 of 
1975 and the Compilation of Islamic Law and the Law on Religious Courts fulfill several reasons that can lead to or influence legal certainty, namely:

a. Outdated rules;

b. Rules that conflict with each other or overlap, either from unclear content or competence;

c. "dependent" rules without implementing rules so that the basic rules cannot be implemented.

d. The 3 (three) reasons above also greatly affect legal certainty and can easily lead to abuse of authority or arbitrary action (Ali, 2010)

Because these 3 (three) reasons greatly affect legal certainty so that it still causes disparity in judges' decisions in deciding divorce cases for non-Muslim couples.

\section{Government And Bureaucratic Certainty}

Four decisions show that the certainty of the government and bureaucracy in Indonesia is still not and does not provide certainty. In fact, the role of the government is very important in maintaining legal certainty. The government may not issue an implementing regulation that is not regulated by law or contravenes the law. The bureaucracy or state administration has a very big influence on legal certainty because it is a place where the law is transformed into a concrete state in various forms of providing legal services to the public.

This role is very much needed, such as in terms of incomplete law (incomplete norm) and the existence of a legal vacuum (vacuum of norm) in marriage law in Indonesia, especially the prevailing laws and regulations in the Religious Courts such as Law Number 1 of 1974 concerning Marriage, Government Regulation Number 9 of 1975, Compilation of Islamic Law, Law on Religious Courts and Law Number 48 of 2009 concerning Judicial Power.

The negligence of this role is due to the incomplete law (incomplete norm) and the existence of a legal vacuum (vacuum of norm) which results in contradicting or contradicting one another's rules. For example, the principle of ius curia novit in Law Number 48 of 2009 concerning Judicial Power is contrary to the principle of Islamic personality in Law Number 3 of 2006 when it is applied to divorce disputes 
for non-Muslim couples. This resulted in non-Muslim couples having to submit to divorce laws in the Religious Courts (Hamami, 2003).

It is very clear that the above will not provide legal certainty to non-Muslim couples because they have to submit to the divorce law in the Religious Courts whereas, the principle of submission can only be applied to disputes in the field of sharia economics in accordance with Article 49 of Law Number 3 Year 2006. This shows that it is very important for a national effort to be serious in regulating laws and regulations, not just making new ones, let alone patchwork. So that there will be no more submission to the divorce law in the Religious Courts by non-Muslim couples.

\section{Court Supremacy}

The four decisions show that judicial certainty in Indonesia is still not and does not provide certainty. In fact, the role of the judiciary is also very important in maintaining legal certainty because the world of justice is one of the components that affect legal certainty. It will provide legal certainty if a case is examined, tried and decided by an appropriate judicial environment. It is well known that of the 4 (four) judicial environments under the Supreme Court, there are only 2 (two) judicial circles that have absolute authority to adjudicate marital cases, namely the General Court and the Religious Court.

Article 50 of Law Number 2 of 1986 concerning General Courts determines that the General Court has absolute authority to try criminal cases and civil cases at the first level. In terms of the authority of civil cases, especially in marriage cases for people seeking justice with religions other than Islam who at the time of carrying out and recording their marriages based on religious law, namely religions other than Islam. Meanwhile, those who have the authority in civil cases, especially marriage cases, are only limited to the people who seek justice who are Muslim and are the absolute authority of the Religious Courts.

The legal considerations of the Panel of Judges which argue that they have the authority to examine, hear and decide non-Muslim divorce cases are as follows: 1) Decision Number 121 / Pdt.G / 2010 / PA.Pkc

The Panel of Judges in this decision stated in legal considerations that even though the parties are Catholic as they admit it, because of the legal relationship between the 
two when they married based on Islamic law, the Religious Court has the authority to examine and try this divorce case.

2) Decision Number 0115 / Pdt.G / 2013 / PA.Ktp

The Panel of Judges in this decision stated in legal considerations that even though the parties were Protestant Christians, because the marriage was carried out based on Islamic law, the Religious Court had the authority to examine and try this case.

3) Decision Number 1226 / Pdt.G / 2013 / PA.SAL

The Panel of Judges in this decision stated in legal considerations that because when the parties were married to Islam and their marriage records were registered at the Office of Religious Affairs, this divorce case is the authority of the Religious Courts to examine and judge them.

4) Decision Number 0044 / Pdt.G / 2014 / PA.Kab.Kdr

The Panel of Judges in this decision stated in legal considerations that although the Plaintiff and / or the parties were non-Muslim, however, based on the principle of Islamic personality which is one of the principles of civil procedural law in religious courts which is an inseparable relationship with the legal considerations to which the parties was Muslim at the time of marriage, therefore the Panel of Judges was of the opinion that in this divorce case it was the absolute authority of the Religious Court because what determined was the marriage relationship which was in effect at the time the marriage took place.

The legal considerations mentioned by the Panel of Judges in the 4 (four) decisions above resulted in the absence of legal certainty because this divorce case was examined, tried and decided by an inappropriate judicial environment, namely the environment of the Religious Courts which had limited authority for Muslim justice seekers. This shows that the divorce case should be examined, tried and decided by the judiciary which has the authority for people who seek justice apart from being Muslim, namely the General Court.

\section{Social Uproar}

The difference in legal considerations in terms of the imposition of the dictum of the decision is very risky for social upheaval because between talak ba'in sughra and fasakh have different legal consequences. As Article 119 stipulates that talak ba'in sughra is talak which cannot be referred to but it is permissible to have a new 
marriage contract with her ex-husband even though it is in idah. From this provision it is very clear that the legal consequence of the imposition of talak ba'in sughra is that it is still possible to carry out a new marriage contract even though it is in idah while the parties to a divorce case are non-Muslims. In contrast to the fall of fasakh. After the marriage is declared fasakh, it breaks without any other legal consequences such as talak ba'in sughra (Sabaeni, 2001). From the imposition of this dictum that will cause a conflict or noise because of disparities in the decisions of cases or cases of the same position. If the problem of submitting oneself to the Islamic divorce law by nonMuslim couples and the disparity in the dictum of the ruling continues, order will not be created. Because, law is not only seen as an convenience or simply to fulfill or satisfy a need, but also contains a dimension of order. Without order, there is not only uncertainty but it will be very detrimental to the interests of the people and can lead to social anarchy.

\section{Conclusion}

Legal arguments against the occurrence of submission by non-Muslim couples in divorce law in the Religious Courts in 4 (four) Religious Court decisions occurred because Law Number 48 of 2009 concerning Judicial Power adheres to the principle of ius curia novit so that the Religious Courts cannot reject divorce cases the reasons for the incomplete norm and the vacuum of norm. Then, strengthen the position of legal certainty on the issue of submission by non-Muslim couples to divorce laws in the Religious Courts. This problem resulted in at least 4 (four) legal uncertainties, namely:

a. The occurrence of legal uncertainty due to incomplete law (incomplete norm) and the existence of a legal vacuum (vacuum of norm) in marriage law in Indonesia.

b. The negligent role of the government and bureaucracy has resulted in a conflict between Law Number 48 of 2009 concerning Judicial Power and Law Number 3 of 2006 resulting in legal uncertainty.

c. The role of the Religious Courts which are not placed on their authority;

d. If the problem of submitting oneself to the Islamic divorce law by non-Muslim couples and the disparity in the dictum of the verdict continues, there will be no order created which risks leading to social upheaval. 


\section{REFERENCES}

Ali, A. (2010). Menguak Teori Hukum (Legal Theory) \& Teori Peradilan (Judicialprudence) termasuk Undang-undang. (Legisprudence) Volume I Pemahaman Awal. KencanaPrenada Media Group

Hamami, T. (2003). Kedudukan dan Eksistensi Peradilan Agama dalam Sistem Tata Hukum di Indonesia. Alumni.

Harahap, Y. (2009). Kedudukan, Kewenangan, dan Acara PA (Undang-undang Nomor 7 Tahun 1989. Sinar Grafika.

Mulyata, J. (2015) Keadilan, Kepastian dan Akibat Hukum Putusan Mahkamah Konstitusi Republik Indonesia Nomor: 100/PUU-X/2012 tentang Judicial Review Pasal 96 Undang-undang Nomor: 13 Tahun 2003 tentang Ketenagakerjaan. Thesis Universitas Sebelas Maret.

Purbasari, I. (2017). Hukum Islam Sebagai Hukum Positif di Indonesia: Suatu Kajian di Bidang Hukum Keluarga. Intrans Publishing.

Saebani, B. A. (2001). Fiqh Munakahat 2. Pustaka Setia

Saebani, B. A. (2008). Perkawinan dalam Hukum Islam dan Undang-undang Perspektif Fiqh Munakahat dan Undang-undang Nomor 1 Tahun 1974 tentang Poligami dan Problematikanya. Pustaka Setia.

Setyowati, R. \& Purbasari, I. \& Fauzan, E.M. (2018). Consumers Spiritual Rights in the Islamic Banking Dispute Out of Court Settlement in Indonesia. Journal of Social Studies Education Research. 9 (4), p. 343

Suleman, Z. (2010). Asas Personalitas Keislaman dalam Kompilasi Hukum Islam (KHI). Jurnal Al-Ulum, 10 (02).

Syaifuddin, M., et.al. (2014). Hukum Perceraian. Sinar Grafika.

Yasin, M. N. (2016) "The Pluralism of Islamic Economic Law: Dialectic of Moslem and non-Moslem in the Development of Sharia Banking in Indonesia", Journal of Indonesian Islam. 10 (01), p. 115, 128.

Yasin, M.N. (2018). Politik Hukum Ekonomi Syariah di Indonesia, UIN-Maliki Press. 